\title{
A Possible Accretion Accompanied by Ophiolite in the Mariana Trench
}

\author{
Eiichi HoNZA* and Hideo KAGAMI** \\ マリアナ海溝におけるオフィオライトをともなつたアクリーション \\ 本座栄一*，加賀美英雄 $* *$
}

要 旨

マリアナ弧の前線斜面および海溝域のエア，ガンによる音波探査とドレッジによる底質 採取を東京大学海洋研究所所属の 白鳳丸 KH-71-1 次航海で 1971 年 2 月の数日間に実施し た。

マリアナ諸島は始新世初期以降の安山岩および玄武岩質の火山岩と石灰質堆積岩から成 つている。マリアナ弧前線の大陸斜面に㵊大層厚 1 秒（往復反射時間）の堆積層が分布し ている (Figs. 2，3，4)。陸側海溝斜面には音響無反射層の堆積物と思われるものが分布し ている。

大陸斜面の堆積物は海溝斜面縁にみられる音響基盤の高まりによつてさえぎられてい る。これら堆積物は側方堆積の傾向をもち，基盤の構造運動による影響もみられる。海溝斜 面縁の高まりは調查海域北方では約 $800 \mathrm{~m}$ の比高があるが，南域にいくにしたがい，しだい に低くなり，最南域では地形上の高まりとしては識別できず，堆積物をさえぎる基盤の高ま りと斜面の傾斜の変換点としてのみ表われている。同様の基盤の高まりは海洋斜面縁の高ま りの陸側にもら一つみられる。

海側海溝斜面にみられる音響透明層はアンチセーティツク断層により切られている。ま た斜面にみられる海山は頂面に反射層らしきパターンがみられ，これは斜面と同栐の傾斜面 となつていることから，斜面形成以前に平頂海山であつた可能性が強く，太平洋プレートの マリアナ海溝への移動にともない傾斜したものと思われる。

Fig. 3 の本調査測線上の大陸斜面に DSDP の site 60 の掘削点が $380 \mathrm{~m}$ 深まである が，その結果，中期中新世の初期から末期にわたる凝灰岩層から成つていることが判明して いる。堆積層は音波探査の結果 600-800 m の層厚があるものと推定される。したがつて，こ れら堆積層はグアム島の Umatac 層に, また下位層の一部は Alutom 層に対比されるもの と思われる。音響基盤の地質時代は判然としないが，一部は Alutom 層に対比される可能性 も否定できない。

海溝斜面縁の高まりの海側斜面におけるドレッジから数多くの変質した 蛇紋岩が採取さ れた。これらの蛇紋岩には蛇紋石, 褐色クローム, olivine, augite, plagioclase, クローム, スピネル, opaque mineral 等が含まれている。また凝灰質堆積物, 有孔虫等が亀裂の中に 含まれている。音波探査記録（profile 1) によるとドレッジ点には堆積層の反射面はみられ ない。したがつて，凝灰質堆積物は蛇紋岩体が隆起したときにもまれ，とり込またものの一 部であると判断される。

マリアナ弧の地背斜域には中生界・古生界がみられない。たとえそれらが存在したとし ても, 現在の状態のなかでの島弧活動は始新世後期以降であることが地背斜域の火山活動か ら推し計られる。海溝斜面縁の蛇紋岩は海溝の形成にともなうアクリーションによつて陸側 海溝斜面に沿って隆起してきたものと思われる。海溝斜面縁付近の堆積層の分布形態から， その発展形態を判断することができる (Fig. 8)。

* Marine Geology, Geological Survey of Japan, Hisamoto, Kawasaki, 213, Japan 工業技術院地質調查所 海洋地質部

** Ocean Research Institute, University of Tokyo, Nakano, Tokyo, 164, Japan 東京大学海洋研究所 


\section{Introduction}

Mariana island arc consists of a trench, frontal arc, inter-arc basin and third arc from east to west and is seperated from the Asian continent by the Philippine basin and other island arc systems observed at the western margin of the basin. Structural framework of the frontal slope of the Mariana arc was discussed on a basis for the geological and geophysical data (KATSUMATA and SYKES, 1969; KARIG, 1971, 1975 ; BRACY and OGDEN, 1972 ; HonzA et al., 1973). A DSDP drilling site locates on the frontal slope east off the Guam island (FISCHER and HEEZEN, 1971).

The frontal arc of the Mariana arc system is asymmetric with a single steep scarp on the western flanks and with a gentle slope covered with sediments in the upper part of the eastern flanks. Continental slope in the eastern flank is interrupted by the mid-slope basement high at the lowest margin (KARIG, 1971), which extends to the whole length of the eastern flank (MoGI, 1972). The word of midslope basement high is now designated for trench slope break (DICKINSON, 1973), which locates in the critical part to separate continental slope and inner (landwardside) trench slope. Mariana island arc has the same topographic features as that in the Izu-Ogasawara (Bonin) island arc, which can be extended well to the both arcs.

Mariana ridge is composed of andesitic and basaltic volcanic rocks and calcareous sediments from late Eocene or older to Pleistocene age, which were reported from exposures on islands of Guam, Rota, Tinian and Saipan (ClOUd et al., 1956 ; SCHMIDT, 1957 ; TRACEY et al., 1964 ; LADD, 1966 ; TODD et al., 1966).

A continuous seismic reflection profiling survey and a sampling by dredges were carried out crossing the frontal slope and trench of the Mariana arc during the KH-71-1 cruise of Hakuho-Maru of the Ocean Research Institute, University of Tokyo from February 11th to 19th, 1971.

Pneumatic sound source of Lamont-Doherty type air-gun of 0.4 liters in air chamber volume was used for the survey. The reflected informations were received by a hand-made hydrophone array which has twenty-five Geo-space MP-17 receiving elements.

Cylinderical dredge bucketes of $40 \mathrm{~cm}$ and $15 \mathrm{~cm}$ in diameter were used with three meter long, $15 \mathrm{~cm} \phi$ chain, and a lead weight of $200 \mathrm{~kg}$. The dredge site locats at $13^{\circ} 53.4^{\prime} \mathrm{N}, 146^{\circ} 17.5^{\prime} \mathrm{E}(4350-4450 \mathrm{~m}$ in water depth).

The survey lines of air-gun crossed the Mariana trench in the area of latitude $12^{\circ} \mathrm{N}$ to $14^{\circ} \mathrm{N}$, off Guam and Rota islands (Fig. 1).

\section{Results}

Maximum 1.0 second thick of the layered sediments is observed on the con- 
tinental slope of the eastern flank (Figs. 2, 3 and 4).

The sediments without layering acoustically are noted on the inner trench slope of the northern section of profil 1 (Fig. 2). The sediments on the continental slope are apparently dummed by the acoustic basement of the trench slope break. They show apparently outward progradation and cover the old ridge, and are cut by faults in the upper continental slope, and they are also deformed by the structual movement of the basement.

The peak at the trench slope break in the northern section has a relative hight of $800 \mathrm{~m}$ from the base of landward side (Fig. 2). However, it tends to decrease in hights toward south, and has a relative hight of $80 \mathrm{~m}$ in the profile 2 (Fig. 3). It disappers on the topographical profile, but can be seen how as a sediment trapping barrier at the slope break. One more ridge is observed in the inside of the ridge which consist the trench slolpe break. Axial direction of the ridges are rather parallel to the trench than the frontal arc axis (Fig. 6). Thin layers of sediments in the inner trench slope of the southern sections may suggest the over-lapping of the younger terrigenous sediments through the trench slope break (Fig. 4).

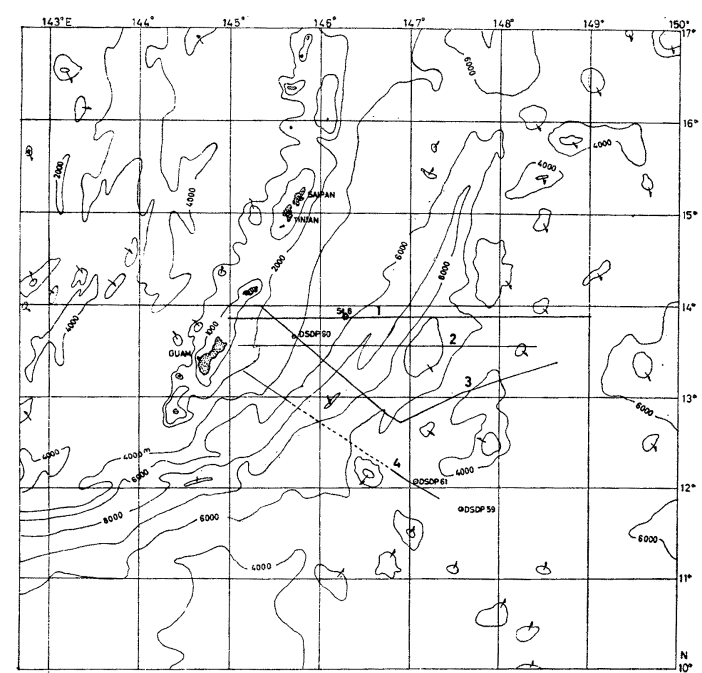

Figure 1. Bathymetry, tracks of continuous seismic reflection profiling survey, a sampled site in the frontal slope and trench of the Mariana arc.

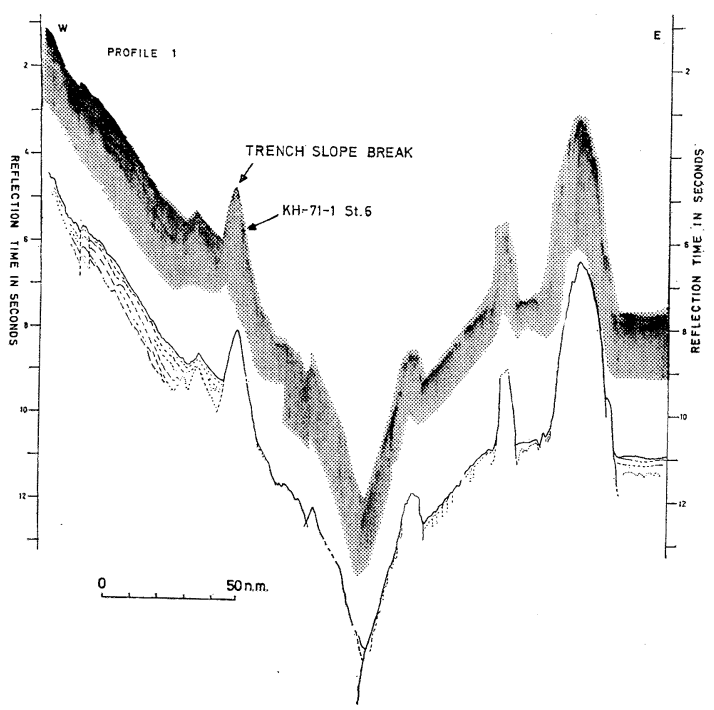

Figure 2. A continuous seismic reflection profile in the Mariana trench. Sediments on the frontal slope are dammed by the mid-slope basement high at the trench slope break. An arrow indicates. The dredged site. 


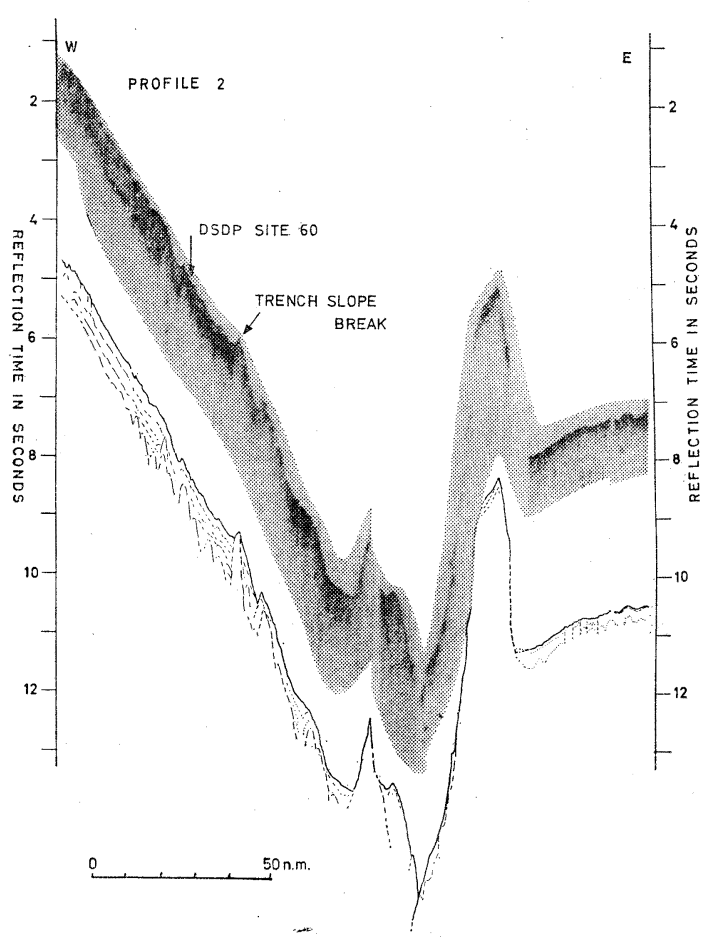

Figure 3. A continuous seismic reflection profile. Mid-slope basement high at the trench slope break is smaller as compered with that in the northern profile. An arrow indicated the DSDP Site 60.

Thin transparent layer lying on relatively thick opaque layer distributes on the oceanic floor of the Pacific Ocean. Many faults which cut those pelagic sediments develop at the upper part of outer trench slope. They may be developed by the same origin as can be seen in the outer trench slope of the Japan trench (HoNZA, 1976).

Many peaks and seamounts are observed in the outer trench slope. One of them has layered sediments on the top as illustrated in profile 2 (Fig. 3 ). It might be a flat-topped seamount once which tilted toward the trench later. One of them has a few steep peaks on the top as illustrated in profile 3 . One of them distributes on the foot of landward side of the trench and has apparently deformed struc-

ture (Profile 2). There is a possibility that they had been seamounts on the oceanic floor, drifted toward the trench by the motion of the Pacific plate toward the trench, then tilted in the outer trench slope and deformed in the trench.

The trench floor has $\mathrm{V}$-shaped profile and does not show any ponded sediments. The floor tends to increase with depth toward south.

DSDP site $60\left(13^{\circ} 40.0^{\prime} \mathrm{N}, 145^{\circ} 41.9^{\prime} \mathrm{E}, 3717 \mathrm{~m}\right.$ deep) locates on the continental slope. Profile 3 crosses just on the site. From the results obtained by drilling, the slope sediments are revealed to be composed of ash layers ranging in age from early middle Miocene to late middle Miocene. Drilling by DSDP is approximately $350 \mathrm{~m}$ in core length, but does not reach the acoustic basement (Fig. 5). The layered sediments on the continental slope have a thickness of 0.8 second in two way reflection time which is observed in Fig. 3. It is approximately $600-800 \mathrm{~m}$ thick estimated from the seismic velocity of $1.7 \mathrm{~km} / \mathrm{s}$ to $2.0 \mathrm{~km} / \mathrm{s}$ (FISCHER et al., 1971). The whole sequence of the layered sediments may be partly correlated to the Umatac and Alutom formations on Guam island which range in age from

$$
-11-
$$


lower Miocene to late Eocene (Table 1). They distribute mainly on the shallower part of the continental slope west of the trench slope break (Fig. 6) and have parallel distributional pattern in thickness to the trench slope break (KARIG, 1971). They cover the inner ridge but are dummed by the outer ridge of the trench slope break in the profile 1. Therefore, the accoustic basement of the inner ridge is uncertain in age, however, there is a possibility that the Alutom formation in late Eocene to early Oligocene on Guam island may be correlated

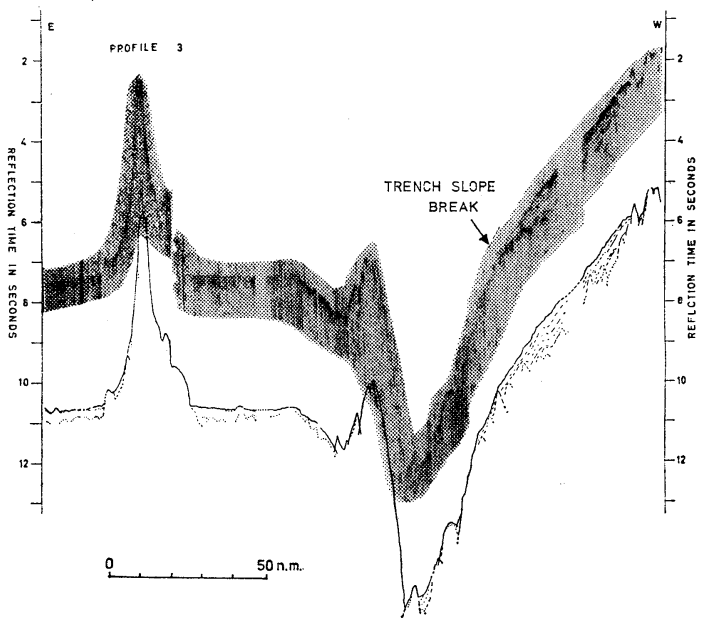

Figure 4. A continuous seismic reflection profile. Mid-slope basement high at the trench slope break dissappears in the topographic impression and shows only as subsurface highs. party to it (Fig. 8).

By dredging in approximately $4500 \mathrm{~m}$ deep at station 6 (Figs. 1 and 2), many fragments of altered serpentinite and tuffaceous rocks with a few to ten centimeters in diameter are obtained. The dredged site is just on the profile 1 and locates in
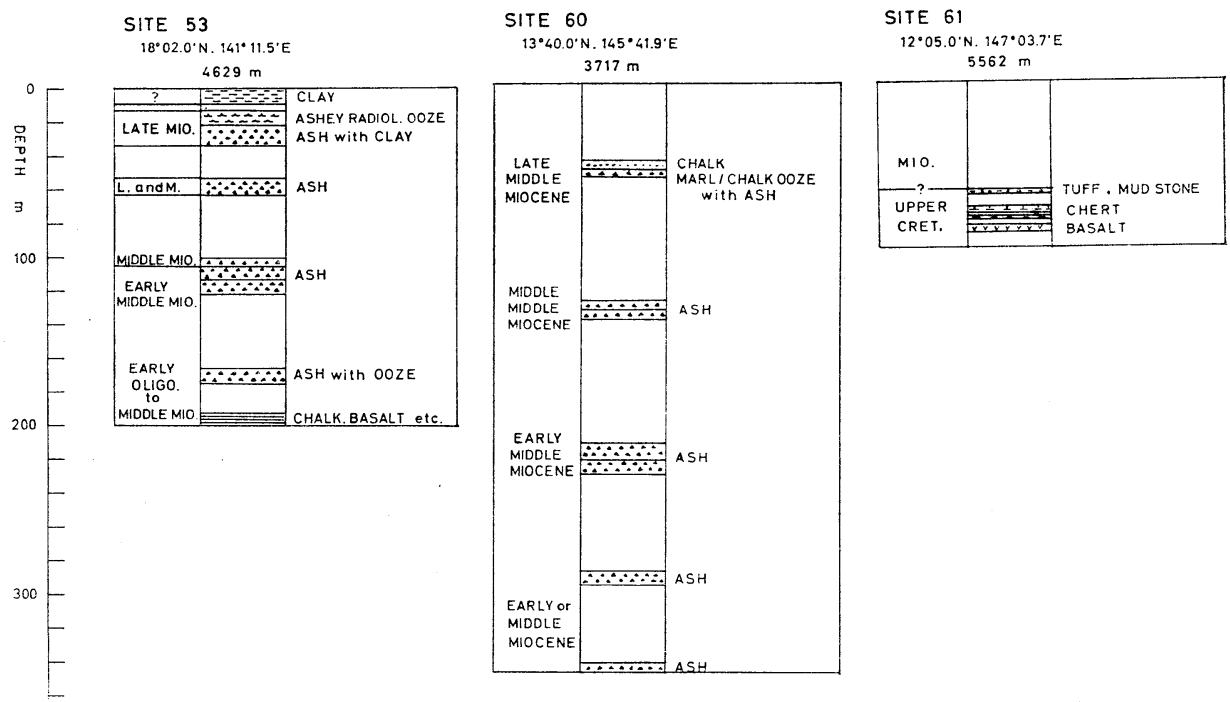

Figure 5. DSDP drilling results of the Sites 53, 60 and 61. Site 53 locates in the sedimint apron on the inner flank of Iwo Jima ridge. Positions of Sites 60 and 61 are shown in Figure 1. 
A Possible Accretion Accompanied by Ophiolite in the Mariana Trench

Table 1. Stratigraphy of the Mariana Ridge (Islands). After LADD (1966)

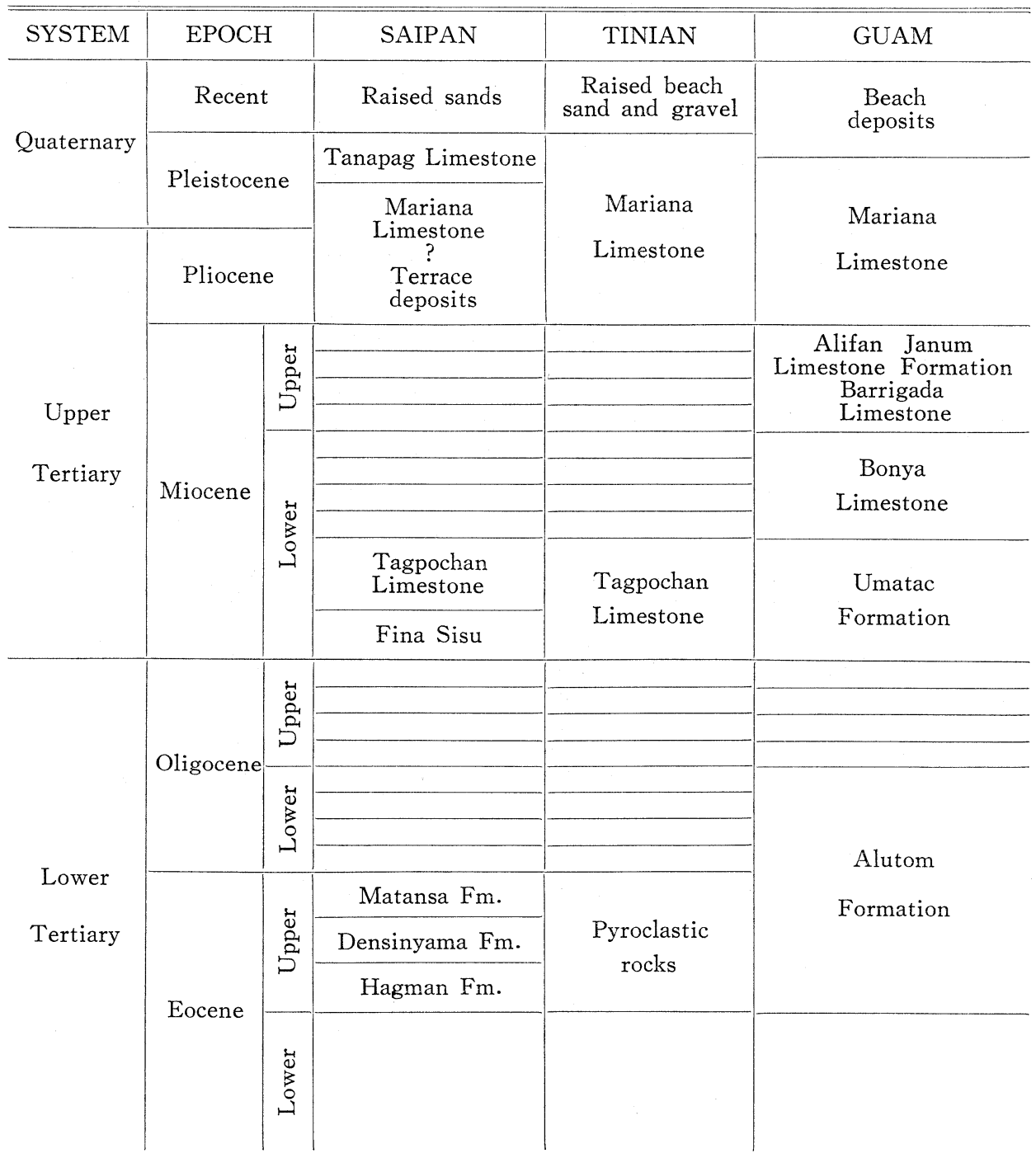

the eastern flank of the trench slope break. Occuring as breccia, serpentinite is composed of serpentine and small amount of brown chromite (Fig. 7). Original rock of the serpentinite appears to be dunite or other kind of ultra-basic rocks. Fragments of olivine, augite, plagioclase, $\mathrm{Cr}$-spinel and opaque minerals are observed among the serpentine, also tuff grains and foraminifera are contained as vein-let (HONZA et al., 1973).

Serpentinites and crushed fragments of tuffaceous sediments correlated to the Umatac formation may suggest the compressional force and uplift at the trench slope. 
From the results of seismic reflection profiling and dredged materials, the trench slope break is suggested to be composed of serpentinite in parts covered by tuffaceous sediments. By seismic reflection profiling, sedimentary cover cannot be distinguished. Therefore, there are two possibilities to interpret. The one is existence of thin cover of Umatam formation on the acoustic basement of the Alutom formation and serpentinite (Model I). The other is that the tuffaceous sediments which supplied from the crest area of the frontal arc are a captured and crushed

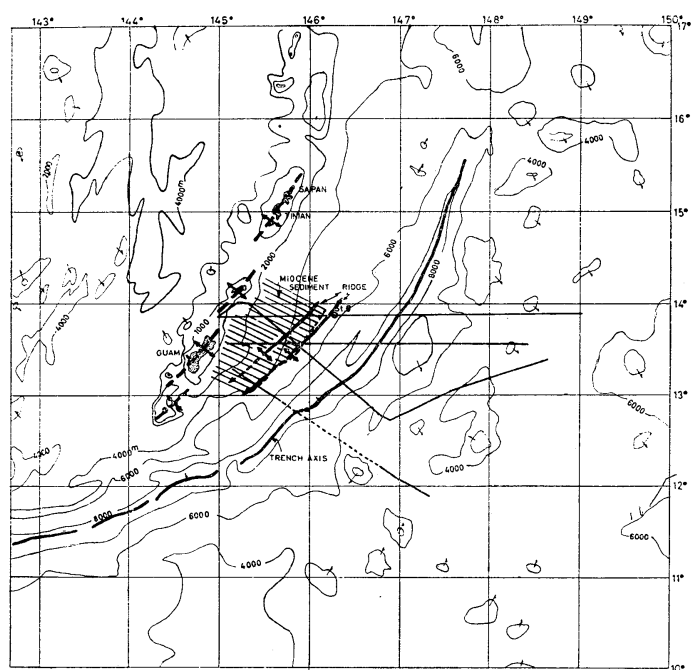

Figure 6. Distribution of Miocene sediments and mid-slope basement highs. Mariana ridge in suggested to be uplifted blocks of islands. one by the uplift of serpentinite blocks (Model II). Reflection nature and bottom configuration suggest the latter is reasonable.

\section{Structural history of Mariana island arc}

Structural framework of Mariana island arc is closely related to that of IzuOgasawara (Bonin) island arc, that is suggested by their topographical and geological resemblances and continuation of both arcs.

Crustal thickness of the arcs in $17 \mathrm{~km}$ in maximum that is rather thinner comparing with other island arcs along the eastern margin of Asian continents (MURAUCHI, et al., 1968), although the surveyed profile by MURAUCHI and others (1968) locates at the junction of the Izu-Ogasawara and the Mariana arcs.

There is no rock exporsure of Mesozoic or Paleozoic era on the southern islands of Mariana ridge (Table 1). However, there is a possibility of occurrence of mafic schists with serpentinite and peridotite bodies similer to those on the Yap island (KARIG, 1971). Mafic schists also distribute on land of New Guinia island and New Caledonia island. They are interpreted as product of obduction of oceanic plate in the late stage of the former island arc activity (DEWEY and BIRD, 1970; COLEMAN, 1972). Mafic schists on Yap island have a possibility of the same history as that on New Guinia and Caledonia islands.

The first trace of the island arc activity in the Mariana arc is volcanic activity in late Eocene age as the pyroclastic formation on Mariana islands. Gentle con- 

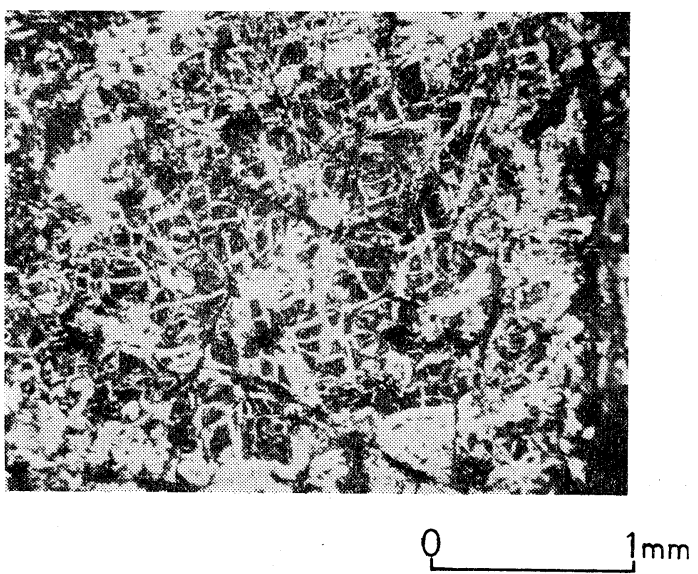

A

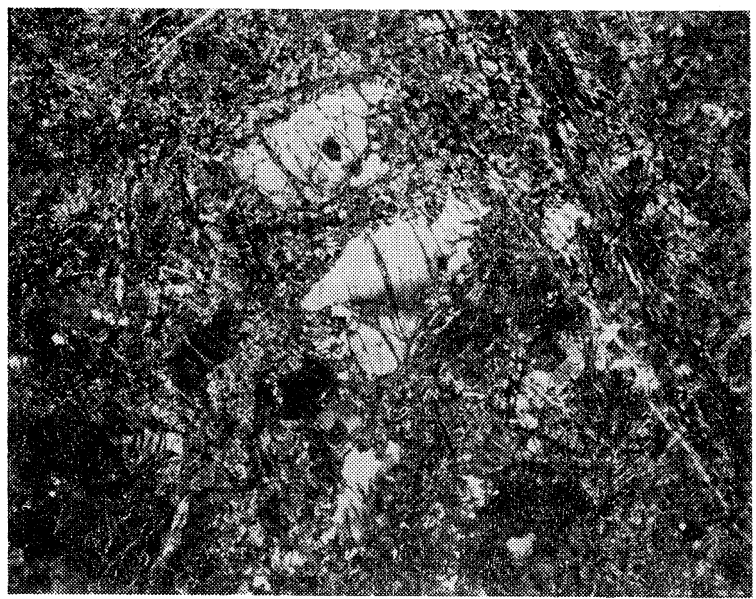

B

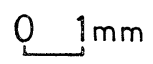

Figure 7. Photomicrographs of typical serpentinite from dredge st. 6. Crossed nicols. Mesh structure of serpentine is well noted in photo A. Olivine is altered to serpentine (photo B). Other minerals are augite, plageoclase, Cr-spinel and opaque minerals. tinental slope developed. Schematic profiles during geological history in Mariana arc are illustrated in Figure 8.

According to Model II the uplift of the trench slope break at the dredged site might take place since or during the deposition of the Umatac formation (Fig. 8).

The uplift of the midslope basement high was also suggested on the canyon floor which could be seen on the northern area of our surveyed area (KARIG, 1971). It is also noted that the canyon floor had tilted toward west during post-Miocene age. Therefore, the uplift of the mid-slope basement high have continued since late Miocene age.

Ultra-basic rocks from the trench slopes were discussed in a few papers. Bowin and others (1966) noted serpentinized peridotite from the northern outer trench slope of

Puerto Rico trench. They interpreted that $5.1 \mathrm{~km} / \mathrm{sec}$ seismic layer might be composed of primarily of serpentinized peridotite with some altered basalt and serpentinized peridotite might be overlain by basalt, chert and Cenomanian siliceous sedimentary rock. The Puerto Rico trench was first discussed to be formed by the tensional force from the gravitational measurment and other geophysical survey 


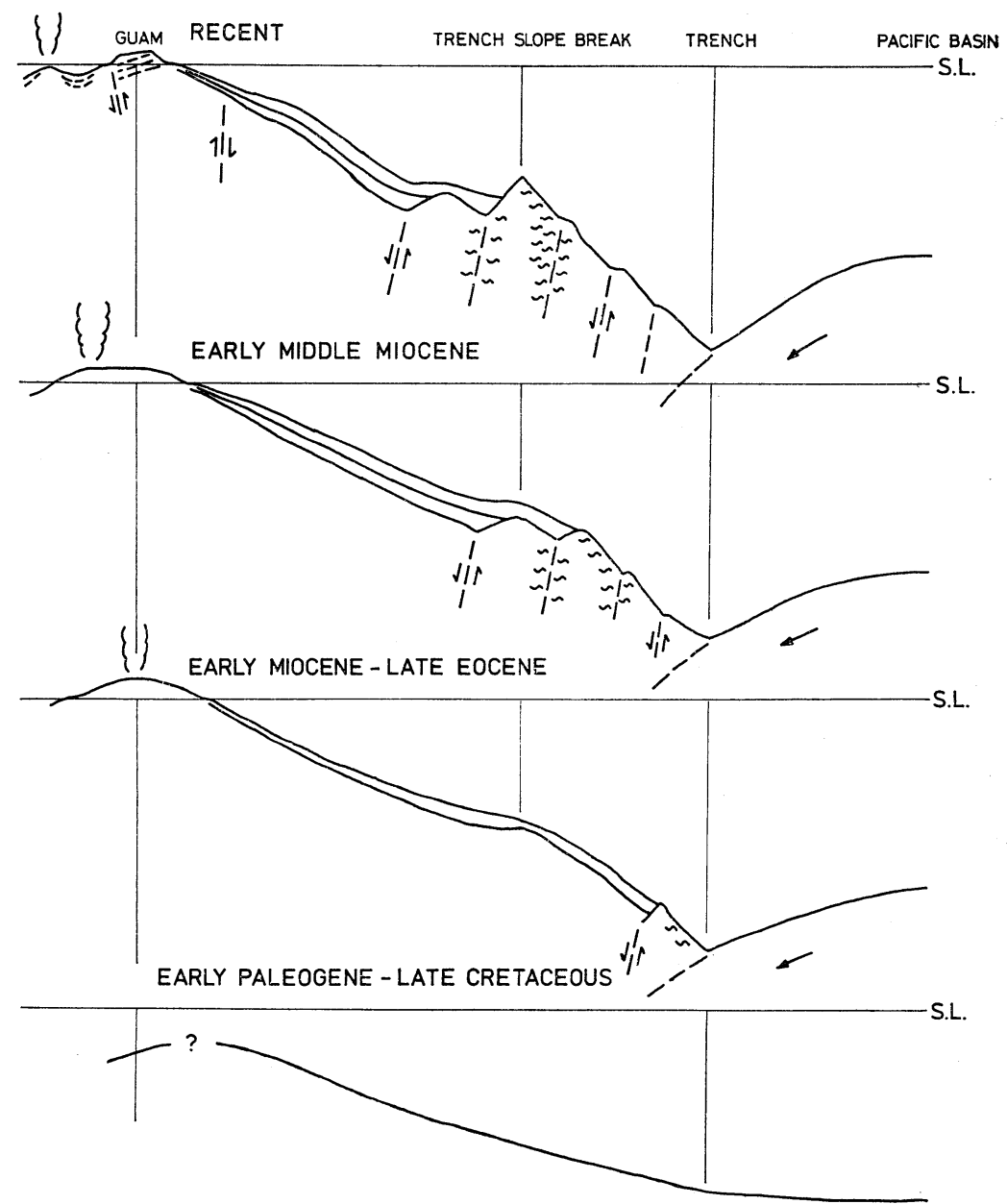

Figure 8. Schematic profiles of Mariana arc and Mariana trench. Subduction zone is suggested to be formed since late Eocene which is deduced from the land history of the crestal islands. The inner ridge might be, at first fomed at the inner side of the trench. The outer ridge which consists the trench slope break todaymight be formed by accretion, since middle Miocene.

(Ewing and HeEzen, 1955; TAlwani, et al., 1959). Direction of the Atlantic plate motion in the Puerto Rico trench is approximately parallel to the trench (MOLNER and SYKES, 1969) and the area may be a extended as a part of a large fracture zone in the Atlantic Ocean (FunNell and SMITH, 1968). Therefore, there is a possibility that the Puerto Rico trench have a different character as comparing with other trenches which are usually recognized to be formed by the subduction of oceanic plate approximately normal to the trench axis. The transform boundary 
would be posturated for the former Mariana arc before Eocene (Fig. 8).

FISHER and ENGEL (1969) reported the ultra-mafic rock from the inner trench slope of the Tonga trench. They dredged fresh to granulated and serpentinized peridotite and dunite from the depth of $9150 \mathrm{~m}$ to $9400 \mathrm{~m}$. The assemblages of rocks suggest that the principal rocks exposed on the inner trench slope are basalts and their derivative of alkalirich volcanics. The sampled peridotite-dunite mass is probably an accumulate formed as sedimented sheets and mats. They said that either of these structure might have been exposed by faulting.

It is doubtful to consider that there was a rest magma chamber or volcano in the lower continental slope or inner trench slope, nevertheless the age of the volcanism is unknown. If so, there is a possibility that stress and temperature conditions under the island arc could have been quite different from the ones posturated by MiYASHIRo (1965), SugIMURA and UYEDA (1973) and others.

A augite dolerite fragment was dredged from Vitiaz deep in the south of Mariana trench (YAGI, 1960). He suggested that the rock was fresh and free from alteration except partial serpentinization of glass, and belonged to the tholeiitic series.

If there was no volcanism in the outer flank of Mariana arc, the ultramafic rock dredged might be supplied from the oceanic crust by the accretional mechanism as schematically illustrated by DEWEY and BIRD (1970), COLEMAN (1972), Dickinson (1973), Kulm, et al., (1974) and SEely, et al., (1974).

Serpentinite in the trench slope break of the Mariana arc is also suggested to be exposed by the structural movement of the transform faulting in the older Pacific basin before Eocene, and then accreted to the continental slope since Eocene (Fig. 8). This tectonic movement has contiued during post-Miocene age.

\section{Acknowledgments}

The data of this paper were obtained by the Hakuho-Maru Cruise, KH-71-1 of Ocean Research Institute, University of Tokyo. We thank Dr. Kenji KonisHI of Kanazawa University, Dr. Tetsuo Harata of Wakayama University, Dr. ChenTung CHUnG of Mining Research and Service Organization, China, and Dr. Naoshi KURODA of Shizuoka University, who helped with the collection of data at sea. We thank Dr. Noriyuki NASU of Ocean Research Institute, University of Tokyo, who was stimulating and helpful. We thank Dr. Yoshimasu KurodA of Shinshu University, who checked the rocks dredged and Mr. Makoto YUASA of Geological Survey of Jayan, who took the photomicrographs of the samples. We thank Dr. Carl BowIN of Woods Hole Oceanographic Institution for his critical reading of the manuscript. 


\section{References Cited}

Bowin, C. O., A. J. NAlwark, and J. B. Hersey (1966) : Serpentinezed peridotite from the north wall of the Puerto Rico trench., Geol. Soc. Amer. Bull., v. 77, p. 257-270.

BRACEY, D. R., and T. A. OGden (1972) : Southern Mariana arc: Geophysical observations and hypothesis of evolution., v. 83, p. 1509-1522.

Cloud, P. E., R. G. Schmidt, and H. W. Burke (1956) : Geology of Saipan, Mariana Islands., U. S. Geol. Survey, Prof. Paper $280 \mathrm{~A}$.

Coleman, R. G. (1971) : Plate tectonic emplacement of upper mantle peridotites along continental edge., Jour. Geophys. Res., v. 76, p. 1212-1222.

DEWEY, J. F., and J. M. BIRD (1971) : Origin and emplacement of the ophiolite suite: Appalachian ophiolites in Newfoundland., Jour. Geophys. Res., v. 76, p. 3179-3206.

Dickinson, W. R. (1973) : Widths of modern arc-trench gaps proportional to past duration of igneous activity in associated magmatic arcs., Jour. Geophys. Res., v. 78, p. 3376-3389.

EWING, M., and B. C. HEEzEN (1955) : Puerto Rico trench topographic and geophysical data. Geol. Soc. Amer. Special Paper 62, p. 255-268.

FISHER, R. L. and C. G. ENGEL (1969): Ultramafic and basaltic rocks dredged from the nearshore flank of the Tonga Trench. Geol. Soc. Amer. Bull., v. 80, 1373-1378.

FICSHER, A. G., et al. (1971) : Initial Reports of the DSDP. v. VI, Washington (U. S. Goverment Printing Office).

HonZA, E. (1976) : Neogene geological history of Tohoku island arc, in N. Nasu ed. Marine Geology, p. 137-154, Tokyo Univ. Press, (in Japanese).

Honza, E., H. Kagami, C. T. Chung, K. Konishi, T. Harata and N. Kuroda (1973): Continuous seismic reflection (air-gun) surveys at Izu-Ogasawara (Bonin), Mariana and Yap Trenches. Y. Tomoda ed., Preliminary Gep. Hakuho-Maru Cruise Kh-71-1, Ocean Res. Inst. Tokyo Univ.

HonzA, E. H., KAGAMI and N. KURODA (1973) : Samples from the walls of the Mariana trench. ibid., p. 73-74.

KARIG, D. E. (1971) : Structural history of the Mariana island arc system. Geol. Soc. Amer. Bull., v. 82, p. 323-344.

KARIG, D. E. and G. F. SHARMAN III. (1975) : Subduction and accretion in trenches. Geol. Soc. Amer. Bull., v. 86, p. 377-389.

Katsumata, M. and L. R. Sykes (1969): Seismicity and tectonics of the western Pacific: Izu-Mariana-Caroline and Ryukyu-Taiwan region. Jour. Geophys. Res., v. 74, p. 5923-5948.

Kulm, L. D. and G. A. Fowler (1974): Oregon continental margin structure and stratigraphy: a test of the imbricate thrust model, in C. A. BURK and C. L. DRAKE eds., The Geology of Continental Margins, Springer-Verlag, Berlin, p. 261-283.

LADD, H. S. (1966) : Chitons and Gastropods (Haliotidae trough Adeorbidae) from the western Pacific islands. Geol. Sur. Prof. Paper, 531.

MiYAshiro, A. (1965): Metamorphic Rocks and Metamorphic Belts. Iwanami book Co., Tokyo (in Japanese)

MoGI, A. (1972) : Bathymetry of the Kuroshio region, Kuroshio-Its physical aspects. Tokyo Univ. Press., p. 53-80.

MolunaR, P. and L. R. Sykes (1969): Tectonics of the Caribbean and Middle American region from seismicity and focal mechanisms. Geol. Soc. Amer. Bull., v. 80, p. 1639-1684.

Murauchi, S. N., Den, S. Asano, H. Hotta, T. Yoshil, T. Asanuma, K. Hagiwara, K. Ichikawa, T. SAto, W. J. Ludwig, J. I. Ewing, N. T. Edgar and R. E. Houtz (1968) : Crustal structure of the Philippine Sea. Jour. Geophys. Res., v. 73, p. 3143- 
3171.

SchmidT, R. G. (1957) : Geology of Saipan, Mariana Islands, petrology of the volcanic rocks. Geol. Sur. Amer. Prof. Paper, 280-B-D.

Seely, D. R., P. R. VAil and G. G. Walton (1974): Trench slope model, in C. A. BURK and C. L. DRAKE eds., The Geology of Continental Margins, Springer-Verlag, Berlin, p. 249-260.

SugimurA, A. and S. UyedA (1973) : Island Arcs, Japan and Its Environs. Elsevier Sci. Publ. Co., Amsterdam.

Talwani, M., G. H. Sutton and J. L. Worzel (1959): A crestal section across the Puerto Rico trench. Jour. Geophys. Res., v. 64, p. 1545-1555.

TODD, R. (1966) : Smaller foraminifera from Guam. U. S. Geol. Sur. Prof. Paper, 403I.

Tracey, Jr., J. I., S. D. Schlanger, J. T. Stark, D. B. DoAN and H. G. MAY (1964) : General geology of Guam. U. S. Geol. Sur. Prof. Paper, 403-A.

WiNTERER, E. L. and W. R. RIEDEL (1971): Introduction, Initial REp. DSDP, v. 7, p. 3-8.

YAGI, K. (1960): A dolerite block dredged from the bottom of the Vitiaz Deep, Mariana Trench. Proc. Japan Academy, v. 36, p. 213-216. 